\title{
The Application of Life Skills in Making of Alum from Can Waste
}

\author{
Beta Febriana $^{1^{*}}$ \\ ${ }^{1}$ Department of Chemistry Education, Islamic University of Indonesia, Yogyakarta, Indonesia
}

\begin{abstract}
Life skills learning is one of the learning processes where students learn various concepts and apply them in daily life. In the process of learning, students are faced with certain situations so that they get a new learning experience perceived benefits. The objective of this research was: 1) to know the mastery of academic and social life skills in practice of making alum from waste can, 2) to know the motivation of students in the implementation of the practice of making alum from waste can, 3) know the concept mastery aspect in the implementation of the practice of making alum of waste can. This research is a quasi-experiment with one-group posttest study design. Research subjects were students of Chemistry Education Department who take inorganic chemistry experiment. Instruments used were observation sheet and rubric indicator of work assessment (for academic and social life skill) and questionnaire (for motivation), and subjective test: pre-test and post-test (for conceptualization). The research data was analyzed by qualitative descriptive analysis technique, that is by calculating the average of every aspect that is assessed and converting it into qualitative criteria. Based on the result of research indicated that student's motivation in practice gets good category while the value of mastery of academic skill and social life skill was in good category and mastery of concept got very good category.
\end{abstract}

Keywords: life skills, inorganic chemistry experiment, motivation, alum (potassium alum)

\section{Introduction}

The development of science and technology is increasingly fast. Basically, the technological developments make human life easier, but it does not rule out the possibility that all technological developments have a negative impact on the environment. The negative impact that occurs is the existence of problems regarding waste. The biggest scourge in every country. Various efforts have been made to reduce waste that cannot be recycled by distinguishing between organic and inorganic waste.

One of the world issues that become the problem is the number of can soft-drink that circulated in the community. Tin waste can be reduced by applying the 5-R principle, namely Reduce, Reuse, Recycle, Replace (Replace) from source, and Replant (replant). However, the most appropriate way to reduce tin waste is to recycle, by utilizing the aluminum content contained in the tin in the manufacture of potassium alum that can be used to purify water [1]. Potassium aluminum sulfate dodecahydrate is a kind of alum formed from reaction with sulfuric acid that has chemical properties $\mathrm{KAl}(\mathrm{SO} 4) 2.12 \mathrm{H} 2 \mathrm{O}$ commonly called "alum" [2]. Alum is one of the types of coagulant needed to assist the process of precipitation of small particles that can-not precipitate gravimetrically in the coagulation process.

Inorganic chemistry practice is regarded as an unattractive practice because the material taught during the lab is considered useless in daily life. In addition, the inorganic chemistry practice is a practice that is considered difficult by most students. This resulted in the motivation of student achievement is low. Students only do practice by following the prescribed procedure without knowing the essence of the practicum which is done in daily life. Students spend a lot of time for the number of credits with one credit weight.

Actually, practice is a learning that can generate motivation or interest of students in learning a thing. Students work in the laboratory and use laboratory tools to prove a concept that has been learned in the classroom. 
Practice can bring the learning experience so that the learning process becomes meaningful which is easy to remember by the students.

To overcome this problem, it is necessary to design an inorganic chemistry lab that is loaded with real-world issues that are easy to apply in daily life. Such practice design is expected to increase students' motivation and scientific attitude in carrying out the practicum.

Life skills are closely related to proficiency, practicing or practicing abilities, facilities and wisdom [3]. Tyler (1947) and Taba (1962) in the Department of National Education (DNE) (2003) argue that Life Skill is one of the focus of analysis in the development of an educational curriculum that emphasize life skills and work. Development of Life Skills prioritizes aspects of relevant skills to be mastered by learners, learning materials in accordance with the level of students' development, learning activities and student activities of learners to achieve competence, facilities, tools, and adequate learning resources and abilities that can be applied in the student life [4].

DNE states that based on the concept of life skills, it can be divided into two main types of generic life skills (GLS) and specific life skills (SLS) [4]. Each of these skills can be divided into sub-skills. Generic life skills consist of personal skills (skills), and social skills (social skills). Personal skills include self-awareness skills and thinking skills. Self-knowledge is basically a self-appreciation as a creature of God Almighty, as a member of society and citizens, and realize and be grateful for the advantages and disadvantages possessed as well as capital in improving himself as an individual who benefits the environment. The tone of thinking includes the ability to recognize and find information, process, and make decisions, and solve problems creatively. While in social skills include communication skills (skills and communication skills) and collaboration skills [5].

\section{Research Methods}

\section{Research design}

The research design used was descriptive qualitative research. The research was made because it was adapted to laboratory conditions and laboratory schedule of solid usage and was only possible if the practice was carried out using one time.

\section{Research Subjects}

Subjects in this study were students of Chemistry Education Study Program at 5th semester in academic year 2017/2018 which were 43 students.

\section{Research Instruments}

Data collection used in this research used test method and non-test method, as in the chart below 


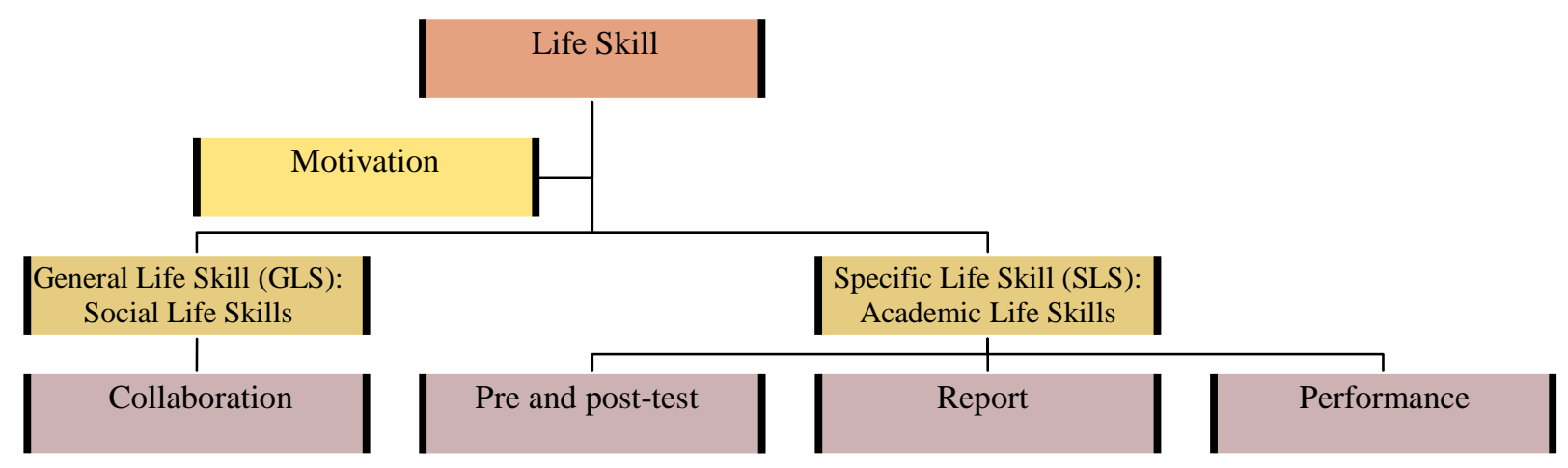

Figure 1. The research instrument used

\section{Result and Discussion}

The application of life-skills based learning on inorganic laboratory was done by inviting students to create a product of alum from tin waste. Assessment in this activity focused on the ability of academic and social life skills. The following elaboration indicator for the aspect of academic life skills and average achievement of each indicator in the 5th semester students on the inorganic laboratory.

Table 1. Achievement on Academic Life Skills Indicator

\begin{tabular}{|c|c|c|c|c|c|}
\hline No & Aspect & Indicator & $\begin{array}{l}\text { Average } \\
\text { Score }\end{array}$ & $\begin{array}{l}\text { Average in } \\
\text { Every } \\
\text { Indicator }\end{array}$ & Category \\
\hline 1. & Pre-Test & $\begin{array}{l}\text { Working Steps } \\
\text { Basic Principles }\end{array}$ & 93.72 & 93.72 & Very Good \\
\hline 2. & Post-Test & Basic Principles & 40.00 & 40.00 & Poorly \\
\hline \multirow[t]{5}{*}{3.} & \multirow[t]{5}{*}{ Report } & Formulating Goals & 89.00 & \multirow{5}{*}{89.23} & Very Good \\
\hline & & $\begin{array}{l}\text { Determining Tools and } \\
\text { Materials }\end{array}$ & 85.00 & & Good \\
\hline & & Designing Work Steps & 84.00 & & Good \\
\hline & & Analyzing Data & 96.00 & & Very Good \\
\hline & & Concluding Data & 92.00 & & Very Good \\
\hline \multirow[t]{5}{*}{4.} & \multirow[t]{5}{*}{ Performance } & Laboratory Safety & 96.00 & \multirow{5}{*}{93.07} & Very Good \\
\hline & & Laboratory Technique & 92.00 & & Very Good \\
\hline & & Liveliness & 95.00 & & Very Good \\
\hline & & $\begin{array}{l}\text { Precision and Accuracy of } \\
\text { the results }\end{array}$ & 93.00 & & Very Good \\
\hline & & Temporary report & 89.00 & & Very Good \\
\hline
\end{tabular}

Table 1. showed that achievement on some indicators of academic life skill had been mastered by students, but there were some surprising facts that the value of students on the post-test aspect scored poorly. In the pre-test indicator, report, and performance, students got more than 80 grades with very good category. Students can master academic skills which mean students also master the scientific way of thinking (scientific method) from formulating goals, determining tools and materials, designing work steps, analyzing data and concluding data 
[6]. In addition, students had mastered the performance of laboratory skills such as laboratory safety, laboratory technique, liveliness, precision and accuracy of the results, and temporary report

Table 2. Achievement on social life-skill indicator

\begin{tabular}{llll}
\hline Aspect & Indicator & Average Score & Category \\
\hline Collaboration & Asking & 82.00 & Good \\
\cline { 2 - 4 } & Responsibility in groups & 87.00 & Very Good \\
\cline { 2 - 4 } & Taking a turn and sharing a task & 96.00 & Very Good \\
\cline { 2 - 4 } & Participation in Group & 92.00 & Very Good \\
\hline Average of Social Life Skill & 89.25 & Very good \\
\hline
\end{tabular}

Table 3. Achievement on motivation

\begin{tabular}{lll}
\hline Aspect & Average Score & Category \\
\hline Student interest in life skills-based practice & 89.00 & Very good \\
\hline
\end{tabular}

The social skills measured in this research were using the ability of cooperation. There were several indicators of collaborative ability that included: asking questions, group responsibilities, taking turns and sharing tasks and participation in groups. Table 2 showed that the average score achieved by students on the ability of cooperation was 89.25 with good category.

The inorganic chemistry practice is one of the coruse in chemistry field that must be mastered by the future teacher. Practice in producing alum from used can waste is one of the titles of inorganic chemistry-based life skills. This practice is full of applications in the daily life of students. Various benefits that can be obtained by students in carrying out this lab are:

- Students are able to apply inorganic chemical applications in their daily life

- Students are able to produce practicum products in the form of alum

- Students can use used waste can.

Aluminum waste containers recycling was highly feasible and could provide many environmental, economic and community benefits to individuals, communities, organizations, companies and industries. Aluminum can were currently recycled to make more aluminum products such as alum, with an energy savings of 95 percent over refining and smelting bauxite ore. Alum was a chemical used in a myriad of applications including water purification, make-up, deodorant, hardening gelatin, baking powders, hardening plaster casts, and as a medicinal astringent [7].

The implementation of inorganic chemistry lab with the title of alum manufacture from this used tin waste was held by one lecturer and an assistant. The practicum assistant was tasked with helping, supervising, asking questions that can lure students to find concepts or flow of thinking, solve problems, and conclude based on facts or observations obtained and assess each member of the student group [8].

\section{Conclusion}

Based on the results of research showed that the ability of academic and social life skills got very good criteria. Meanwhile, students got an average score of 86.00 on achievement motivation with very good criteria. 


\section{References}

1. Purnawan, I dan Ramadhani, R. 2014. Pengaruh Konsentrasi KOH Pada Pembuatan Tawas Dari Kaleng Aluminium Bekas. Jurnal Teknologi No 6 Vol 2: 09-119

2. Ugwekar, R.P. and Lakhawat, G.P., 2012. Potash Alum from Waste Aluminum Cans and Medicinal Foil. IOSR Journal of Engineering (IOSRJEN) Vol 2, Issue 7, 62-64

3. Towns, M.H., Kreke K. and Fields, A. 2000. An Action Research Project: Student Perspective s in Small- Group Learning in Chemistry. Journal of Chemical Education, 77, 11-115.

4. Depdiknas. 2003. Pengembangan Model Pendidikan Kecakapan Hidup. Jakarta: Pusat Kurikulum Badan Penelitian dan Pengembangan Depdiknas

5. Broad Based Education. 2002. Pendidikan Berorientasi Kecakapan Hidup (Life Skills) melalui Pendekatan Broad Based Education (BBE). Jakarta: Departemen Pendidikan Nasional

6. Febriana, B.W. 2017. Analysis of student's achievement motivation in learning chemistry. International Journal of Science and Applied Science: Conference Series (IJSASCS). Vol (1) No. 2

7. A.U Birnin-Yauri and Musa Aliyu, 2014, Synthesis and Analysis of Potassium Aluminium Sulphate (Alum) from Waste Aluminium Can. International Journal of Advanced Research in Chemical Science (IJARCS) Volume 1, Issue 8, October 2014, PP 1-6

8. Endang Widjajanti, Eli Rohaeti, and Isana Syl. Penerapan Praktikum Kimia Bermuatan Life Skills Sebagai Upaya Mempersiapkan Calon Guru Yang Berkarakter 